Dig. Surg. 1987;4:I-V

\title{
Contents, Vol. 4, 1987
}

\section{No. 1}

No. 2

\section{Review Article}

Sphincter-Sparing Operations for Chronic Ulcerative Colitis.

Current Alternatives

Pemberton, J.H.; Beart, R.W., Jr

Original Paper

Beta-Adrenergic Inhibition of Pancreatic Secretion in Dogs

Joehl, R.J.; Rose, R.C.; Nahrwold, D.L

Correlation between Atherosclerotic Lesions of Cystic and

Hepatic Arteries and Gallbladder Disease

Vauthey, J.-N.; Mosimann, F.; Gardiol, D.; Mosimann, R. 14 Mucin Abnormalities in the

Radiation-Damaged Colon

Dawson, P.M.; Galland, R.B.; Rees, H.C.; Hershman, M.J.;

Spencer, J.; Wood, C.B

Recurrent Gastric Cancer after Absolute Curative Resection

Habu, H.; Sunagawa, M.; Takeshita, K.; Endo, M 22

Chronic Hypercalcemia Effect on Total Antral Gastrin Cell

Counts

Saik, R.P.; Moore, C 29

Effect of Meal Viscosity on Postprandial Hyperglycemia in

Patients Who Have Undergone Total Gastrectomy

Harju, E.; Nordback, $1 \quad 33$

Biliary Surgery in Diabetic Patients: Statistical Analysis of 189

Patients

Reiss, R.; Deutsch, A.A.; Nudelmann, J 37

Surgical Management of Crohn's Disease: How Much to

Resect?

Jaeck, D.; Rico, E.; Manunta, A.; Bergamaschi, R.; Paris, F.; Bruant, P.; Camilleri, G.; Baumann, R.; Adloff, M.;

Arnaud, J.P.; Oilier, J.C.; Weill-Bousson, M 41

Case Report

Pyogenic Pericarditis as a Complication of Benign Bile Duct Stricture Colovic, R.; Vujadinovic, B.; Kalimanovska, D.; Colovic, M. 45

Short Communication

Diagnosis of Small Bowel Bleeding due to Ectopic Gastric

Mucosa Ulcerations

Rakovec, S.; Fettich, J 48 


\section{Discussion Panel}

Treatment of Acute Necrotizing Hemorrhagic Pancreatitis Eiseman, B.; Norton, L.; Van

Stiegmann, G.; Imrie, C.W.; Kümmerle, F.; Mercadier, M.; Hollender, L.F. (Moderator) 52

Original Paper

Current State of Diagnosis and Therapy of Early-Stage Gastric

Cancer in Japan

Hiki, Y.; Sakakibara, Y

Follow-Up Results of Surgical Treatment in Chronic Pan

creatitis

Köhler, H.; Schafmayer, A.; Peiper, H.-J 67

Glucose Tolerance and Insulin and Gastric Inhibitory Polypeptide Responses following Intraduodenal Glucose Load ing in Dogs with Obstructive Jaundice

Yoshiya, K.; Yamamura, T.; Ishikawa, Y.; Utsunomiya, J.;

Takemura, J.; Seino, Y 76

Detection of Extraintestinal and Intestinal Abnormalities in Inflammatory Bowel Disease by Ultrasound

Schölmerich, J.; Braun, G.; Volk, B.A.; Spamer, C; Hoppe-

Seyler, P.; Gerok, W 82

Hepatic Tumors and Paraneoplastic Syndromes

Morel, Ph.; Rohner, A 88

Prediction of Outcome following Sugiura's Procedure in $\mathrm{Pa}$

tients with Liver Cirrhosis. A Multiple Linear Regression

Analysis and Scoring System

Ouchi, K.; Abe, M.; Sato, T 93

Endoscopic Percutaneous Gastrostomy

Rückauer, K.; Salm, R.; Waldmann, D

Retrosternal Esophagogastrostomy with the EEA Stapler after Subtotal Resection of the Esophagus: Application and Results

Imamura, M.; Ohishi, K.; Mizutani, N.; Yanagibashi, K.; Naito, M.; Shimada, Y.; Hattori, Y.;

Satomura, K.; Tobe, T. 101

Reduction of Postprandial Hyperglycemia by Guar Gum in

Symptomatic Patients 5-10 Years following Proximal Se

lective Vagotomy

Harju, E.; Mäkelä, J 106

Operative Results of Side-To-Side Choledochoduodenostomy for Cholelithiasis

Kinami, Y.; Takata, M.; Yamamoto, H.; Saito, H.; Aonuma,

K.; Takashima, S 110

Case Reports

Hemobilia following T-Tube Drainage of the Common Duct

Van Schil, P.; Schoofs, E 117

Anicteric Presentation of Hilar Cholangiocarcinoma: Anatom

ical and Pathological Considerations

Hadjis, N.S.; Carr, D.; Hatzis, G.; Benjamin, I.S.; Heming

way, A.; Blumgart, L.H 
Endoscopic Removal of a Granular Cell Tumor of the

Esophagus

Roy, A.K.; Hamilton, M.P.; Reddy, S.B 123

IV

Contents

No. 3

No. 4

Original Paper

One Thousand One Hundred and Fifty Proximal Gastric Va-

gotomies for Duodenal and Related Gastric Ulcer. Techni

cal Modifications That Improve Results

Narbona, B.; Davila, D.; Villalba, R.; Lloris, J.M.;

Narbona-Calvo, B 125

Biliary Tract Obstruction Caused by Pancreatic Pseudocysts: Treatment and Outcome

Weaver, D.W.; Bouwman, D.L.; Berg, P.M. van den;

Sugawa, C; Walt, A.J 133

Surgical Inversion: The Safer Way to Operate a Noninflamma

tory Appendix

Meissner, K.; Meiser, G 137

Peroperative Ileojejunoscopy in Peutz-Touraine-Jeghers Syndrome. Three Cases Favre, J.P.;

Haas, O.; Hillon, P.; Mercier, J.F.; Margueritte, A. 144

Diagnosis and Treatment of Recurrent Colorectal Cancer

Tobe, T.; Maetani, S.; Nishikawa, T.; Nagai, T.; Iijima, Y.;

Maruoka, Y.; Onodera, H.; Kan, N.; Morino, T 147

New Design to Examine Colorectal Cancer Cause and Sur

vival. The Melbourne Colorectal Cancer Study

Kune, G.A.; Kune, S 156

Triple Radiotelemetric Pill Study of Postoperative Ileus in Man Morris, D.L.; Clark, A.G.;

Evans, D.F.; Hardcastle, J.D. . 160

Case Reports

Congenital Heal Mucosal Septum and Phytobezoar with Acute

Episode of Small Bowel Obstruction in an Adult

Albu, E.; Nyshadham, S.; Iyer, S.; Gerst, P.H 164

Combined Left Gastric-Distal Splenorenal Shunt for Bleeding

Gastroesophageal Varices

Ross, C.B.; Potts, J.R., III 167

Perforated Gastric Tuberculosis: A Rare Complication of a

Rare Disease

Fink, A.S.; Doty, J.E.; Tompkins, R.K.; Cochran, A.J.;

Cerise, E $\quad 171$

Granular Cell Tumor of the Common Bile Duct. Report of a

Case and Review of the Literature

Ham, A.C. van der; Meijer, W.S.; Ingh, H.F.G.M. van den;

Essen, H.A. van 176 
Announcement $\quad 180$

Original Paper

Metachronous Colorectal Malignancy following Right Hemi-

colectomy for Colon Cancer, with Special Reference to

Increased Levels of Fecal Bile Acids

Kaibara, N.; Ikeguchi, M.; Koga, S.; Ikawa, S

Does Preoperative Biliary Drainage Allow an Improvement of

Nutritional Status in the Jaundiced Patient?

Halliday, A.W.; McPherson, G.A.D.; Benjamin, I.S.; Blum-

gart, L.H 187

Gangrenous Appendicitis. Intraoperative Prophylaxis with

Single-Dose Cefoxitin

Søreide, J.A.; Krag, L.E.; Klevgård, G.; Skreden, K. ... 192 Which Operation for Perforated

Duodenal Ulcer?

Foster, M.C.; Morris, D.L 196

Timing of Surgical Intervention for Acute Cholecystitis

Auguste, L.-J.; Angus, L.; Wisc., L 199

Transphrenic Access to the Lower Mediastinum. Thoracic

Vagotomy through Abdominal Approach

Narbona, B 204

Use of a Breast Implant in 12 Patients to Prevent Small-Bowell

Injury in High Postoperative Irradiation for Pelvic Cancers

Elias, D.; Lasser, P.; Eschwege, F.; Wibault, P.; Simon, P.;

Mandelbrot, L 207

Does Cholecystectomy Increase Operative Risk of Colonic

Surgery? A Matched Case-Control Study

Sarli, L; Gafà, M.; Pietra, N.; Longinotti, E 212

Medical Treatment of Gastric Ulcer: Long-Term Results in

103 Cases

Andreoni, B.; Salvini, P.; Biffi, R.; Sallusti, M.; Castagna,

V.; Bensi, E.; Bevilacqua, G 216

Case Reports

Obstruction from Brunners’s Adenoma. A Rare Complication

of a Rare Tumor

Jennings, H.; Lintner, T.; Bradley, E.L., III; Amerson, J.R. 221 Right Subphrenic Abscess

Caused by an Ingested Bone

Pomeranz, S.; Gimmon, Z.; Lebensart, P 225

Focal Ischaemia of the Caecum: Another Pitfall in the Management of the Appendicular Syndrome (With 1 color

plate)

Hubens, A.; Van Thielen, F.; Beelaerts, W 228

Extensive Lye Injury of the Stomach and Duodenum

Seror, D.; Zamir, O.; Lernau, O.Z.; Nissan, S

Acknowledgement to the Reviewers 233

Author Index 234

Subject Index 236 
